\title{
A preliminary study of the cytotoxicity of the protein extract of Chrysobalanus icaco L. and Eugenia astringens Cambess., commercialized in markets
}

\author{
Thaís A. Pedrete ${ }^{1 \mathrm{a}^{*}}$, Julianderson O.S. Carmo ${ }^{2}$, Emiliano O. Barreto ${ }^{2}$, Josino C. \\ Moreira $^{1}$ \\ ${ }^{1}$ Center for Studies on Workers' Health and Human Ecology, National School of Public \\ Health - Oswaldo Cruz Foundation, Rio de Janeiro, RJ, 21041-210, Brazil. \\ ${ }^{2}$ Institute of Biological Sciences and Health - Federal University of Alagoas, Maceió, \\ AL, 57072-900, Brazil.
}

\section{Abstract}

The use of plants and their products for medical treatment is very common procedure in Brazil, especially for treatment of diabetes. In fact, several plants can demonstrate hypoglycemic effects in vitro assays. However, the use for human treatment requires the knowledge of their toxicological properties. The aim of this study was to evaluate the effect of protein extracts of Chrysobalanus icaco collected from natural habitats and of Eugenia astringens acquired from the market of Rio de Janeiro on the viability and migration of fibroblasts. E. astringens has a similar morphology as C. icaco and it is sold as Chrysobalanus in a popular market in Rio de Janeiro. Being a different plant, E. astringens expresses different proteins, and its protein extract has proved to possess higher toxic properties than $C$. icaco does. Cytotoxicity assays indicated that, as the protein extract concentration increases, fibroblast viability decreases. Only the E. astringens extract displayed cytotoxicity at all concentrations, in addition to reduced fibroblast migration. The results obtained in this study demonstrates that it's necessary integrative policies for rational use of medicinal plants and their commercialization, since the current use of medicinal plants may be inadequate and it is of great importance for Public Health.

\section{Keywords}

Cytotoxicity; Protein extract; Hypoglycemic plant; Chrysobalanus icaco; Eugenia astringens; popular markets

Abbreviations: MAD, Mercadão de Madureira; PG, Praia Grande; RMA, Restinga de Massambaba; AL, Marechal Deodoro; MTT, 3- (4,5-dimethylthiazol-2-yl)-2,5-diphenyltetrazolium bromide.

${ }^{\mathrm{a}}$ Present address: Department of Physiological Sciences, Institute of Biology Roberto Alcantara Gomes State University of Rio de Janeiro (UERJ), Rio de Janeiro, RJ, 20550-170, Brazil.

*Corresponding author: tha.pedrete@gmail.com (Thaís A. Pedrete) 


\section{Introduction}

Several plants are widely used for medical purposes by the population, but this use is most often made from a lay indication, without knowing the risks of toxic effects. Besides, there is no guarantee of the provenance and proper storage of these supposedly "medicinal plants". It is clear that there is a lack of incentive and scientifically-based information to integrative and complementary practices and actions to promote the safe and rational use of medicinal plants, including information on how the species should be prepared and used by the population (Bochner et al., 2012).

The leaf extract (tea) of the plant Chrysobalanus icaco L., a species of restinga popularly known as abajerú, is used in folk medicine because it exerts biological activities, such as the decrease of blood sugar levels, being indicated for the treatment of diabetes, besides be diuretic and antioxidant (Venancio et al., 2018). Another plant (Eugenia astringens, Cambess.) which is morphologically similar to C. icaco, also is known by the same popular name of abajerú and is commercialized as Cicaco (Bochner et al., 2012; Silva and Peixoto, 2009). These two species may not possess the same therapeutic and toxicological properties, which are of concern to Public Health. The attribution of hypoglycemic activity to E. astringens may indicate a misconception since other species of Myrtaceae have hypoglycemic potential (Silva and Peixoto, 2009). So, in order to clarify the toxicological aspects of the extract obtained from these 2 plants, a cytotoxic assay was performed.

For cytotoxicity studies in animal cells several techniques, using distinct cell types as a target, are available. Cytotoxicity means the determination of any toxic effecs at the cellular level, such as changes in membrane permeability, cell death or enzymatic inhibition resulted from exposure to a toxicant, in this case, the studied plants or plant products (Stockert et al., 2012).

Cell viability can be evaluated by several methods, among which the one which involves the conversion of 3-(4,5-dimethylthiazol-2-yl)-2,5-diphenyltetrazolium bromide (MTT) to formazan by mitochondrial reactivation in active-living cells (Zandi et al., 2016). The MTT assay is a standard colorimetric assay that estimates the cytotoxic potential of the samples, in addition to measuring the cellular proliferation of drug agents. Cell viability is expressed as a percentage of live cells from the tested material, comparing with the percentage of cells of the cytotoxicity positive control (Stockert et al., 2018). 
Another test to evaluate the toxicity of the plant extract is the Scratch Wound

67 Healing Assay, which allows measuring the migration of cells that is a phenomenon

68 present in the healing process. It is a method in which a crack imitates a wound in a

69 monolayer of confluent cells so that the cells at the edge gradually move towards the

70 crack (Manoj et al., 2009). Wound healing is the process of repairing and regenerating

71 the dermis and epidermis that accompanies the lesions (Liang et al., 2007; Pitz et al.,

72 2016). The evaluation of the healing activity of plant extracts is scarce at the cellular

73 level. Fibroblast cultures have been proposed as a method for the investigation of

74 wound healing activity, since these cells are the main source of extracellular connective

75 tissue matrix and the migration of fibroblasts is considered vital for rapid and effective

76 skin repair damaged (Manoj et al., 2009).

77 The lack of data about the toxicity of the protein extract of these 2 plants 78 commercialized as abajerú ( $C$. icaco and E. astringens), protein extracts of

79 Chrysobalanus icaco collected directly from its natural habitats and of Eugenia

80 astringens acquired from the market of Rio de Janeiro was performed using the viability

81 and migration of fibroblasts assay.

82

83 2. Material and methods

84

\subsection{Plant sampling}

Chrysobalanus icaco leaves were collected directly from its natural habitats,

88 Praia Grande - Arraial do Cabo- RJ (PG; -22,9696606, -42,0302859), Restinga de 89 Massambaba - RJ (RMA; -22,9337727, -42,4267012), Marechal Deodoro - AL (AL; 90 9,7823233, -35,852364), as shown in the map (Fig. 1). Eugenia astringens leaves were 91 purchased on the market Mercadão de Madureira located in the North zone of Rio de 92 Janeiro city. 
93

94

95

96

97

98

99

100

101

102

103

104

105

106

107

108

109

110

111

112

113

114

115

116

117

118

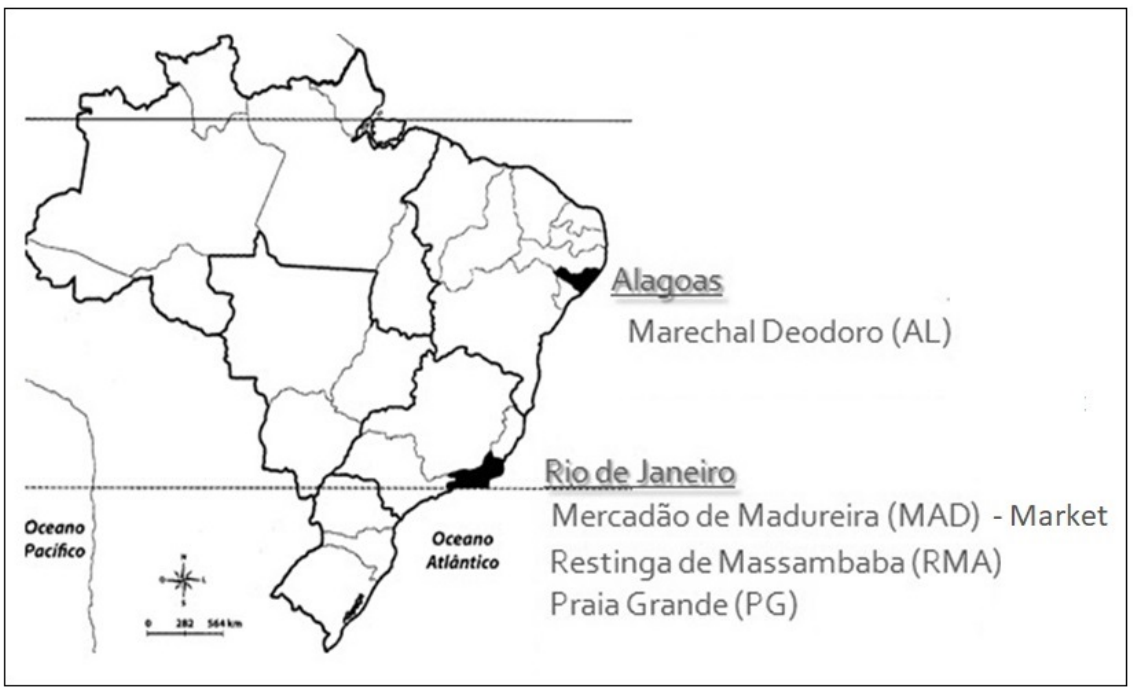

Fig. 1. Sampling sites. AL - Marechal Deodoro, MAD - Mercadão de Madureira, RMA - Restinga de Massambaba, PG - Praia Grande (PG).

\subsection{Protein extraction}

About $10 \mathrm{mg}$ of each lyophilized sample were weighed into microtubes in triplicate. Samples were incubated in the presence of $400 \mu$ lysis buffer (4\% SDS $0.1 \mathrm{M}$ Tris- $\mathrm{HCl}$ buffer $\mathrm{pH} \mathrm{7.6)}$ at $95{ }^{\circ} \mathrm{C}$ for $15 \mathrm{~min}$ in a thermomixer. The lysate extract was frozen at $-80{ }^{\circ} \mathrm{C}$ for further quantification of total proteins by the Lowry method (Lowry et al., 1951), using bovine serum albumin $(2.0 \mathrm{mg} / \mathrm{mL})$ as the standard for the analytical curve. Samples $(2 \mu \mathrm{L})$ and analytical curve $(0,10,20,30,40,50,60$ and $70 \mu \mathrm{g} / \mathrm{mL})$ were read in a Jasco V-530 spectrophotometer at the wavelength of $750 \mathrm{~nm}$.

\subsection{Cytotoxicity evaluation of protein extracts}

This assay was performed as follows:

\subsubsection{Cell culture}

Fibroblasts (3T3 cell line) were kept in medium Dulbecco's Modified Eagle Medium (DMEM), containing $10 \%$ fetal bovine serum, L-glutamine $(2 \mathrm{mM})$ and gentamicin $(40 \mu \mathrm{g} / \mathrm{mL})$ in incubator at $37{ }^{\circ} \mathrm{C}$ and $5 \% \mathrm{CO}_{2}$.

\subsubsection{Cell viability assay}


119 The effect of the protein extracts of Eugenia astringens (Mercadão de 120 Madureira) and Chrysobalanus icaco (Restinga de Massambaba - RJ, Marechal - AL, 121 Praia Grande - RJ) on fibroblasts viability was evaluated through the MTT assay 122 (Mosmann, 1983).

123 The cells were seeded in a 96 well plates and placed in $\mathrm{CO}_{2}$ incubator overnight.

124 The cells were then treated with different sample solutions $(1,5,10$ and $20 \mu \mathrm{g} / \mathrm{mL})$ in 125 four replicates. The control group was treated only with the medium (DMEM). After 126 treatment, a solution of MTT (3-(4,5-dimethylthiazol-2-yl)-2,5-diphenyltetrazolium 127 bromide) (5 mg/mL in phosphate buffered saline - 1X PBS pH 7.4) was added to each 128 well and incubated for 4 hours. Subsequently, the supernatant was discarded and $150 \mu \mathrm{l}$ 129 of dimethyl sulfoxide were added for solubilization of the formazan crystals. The 130 absorbance was measured using a microplate spectrophotometer (DTX 880 Multimode 131 Detector, Beckman Coulter), adjusted to $595 \mathrm{~nm}$, and the optical density was calculated 132 (Equation 1).

\subsubsection{Scratch wound healing assay}

The effect of the protein extracts of Eugenia astringens (Mercadão de 143 Grande - RJ - branch) on fibroblast migration was evaluated through cell migration 144 technique, method described by Liang et al. (2007).

145 Cells ( $7 \times 10^{4}$ cells / well, measured by the Newbauer's chamber) were seeded in 146 24-well plates and maintained overnight for cell adhesion and formation of a monolayer 147 at approximately $80 \%$ confluency. A small part of the monolayer was removed in the 148 middle of the plate with a $200 \mu \mathrm{L}$ pipette tip (a scratch is placed on the monolayer and 149 the part removed is discarded). Cells were washed with phosphate buffered saline and 150 treated with $5 \mu \mathrm{g} / \mathrm{mL}$ of the samples or culture medium (control) in triplicate. This 151 exposure concentration at which some effects started to be observed in the cell viability 152 assay was chosen to perform the present assay. Cell migration was assessed by 153 photomicrographs at 0 - and 24-hours post-exposure using an inverted microscope 
154 (Olympus IX70) with digital camera to measure the area of wound closure. The 155 photomicrographs were analyzed using Image $\mathbf{J}$ software and cell migration was 156 expressed as the area in pixels, so that the percentage of closure of the initial area formed was determined quantitatively (Equation 2).

158

Equation 2 - Migration rate of fibroblasts submitted to the cell migration assay.

$$
\% \text { migration }=\frac{\left(A_{0}-A t\right)}{A_{0}} \times 100
$$

$$
\begin{gathered}
\mathrm{A}_{0}-\text { original area }(\text { time }=0 \mathrm{~h}) \\
\mathrm{A}_{\mathrm{t}}-\text { area after the scratch }(\text { time }=24 \mathrm{~h}) .
\end{gathered}
$$

\subsection{Statistical analysis}

The results of the cell viability and migration tests were expressed as mean \pm standard error, performed in triplicate and analyzed statistically using analysis of variance (ANOVA), followed by Newman-Keuls post-test. The results were considered significant when $\mathrm{p}<0.05$. All results were analyzed using GraphPad Prism® software version 5.01 (GraphPad Software Inc, San Diego CA, USA).

\section{Results}

\subsection{Plant identification and protein concentration}

The identification of the studied plants was performed by a botanist from the Jardim Botânico do Rio de Janeiro. The plant purchased on the market (Mercadão de Madureira) was identified as Eugenia astringens Cambess., of family Myrtaceae, and the plants collected in Marechal Deodoro, Massambaba and Praia Grande as Chrysobalanus icaco L., plant from family Chrysobalanaceae.

Chrysobalanaceae can be morphologically diffeenciate from the Brazilian Myrtaceae species, by some characteristics, such as phylotaxia, which is alternating (and opposite in Myrtaceae). Nevertheless, the similar form of the leaves of $C$. icaco and E. astringens can cause confusion (Fig. 2), the E. astringens leaf has a fold around it facing the abaxial part (Fig. 2c) not found in C. icaco. 


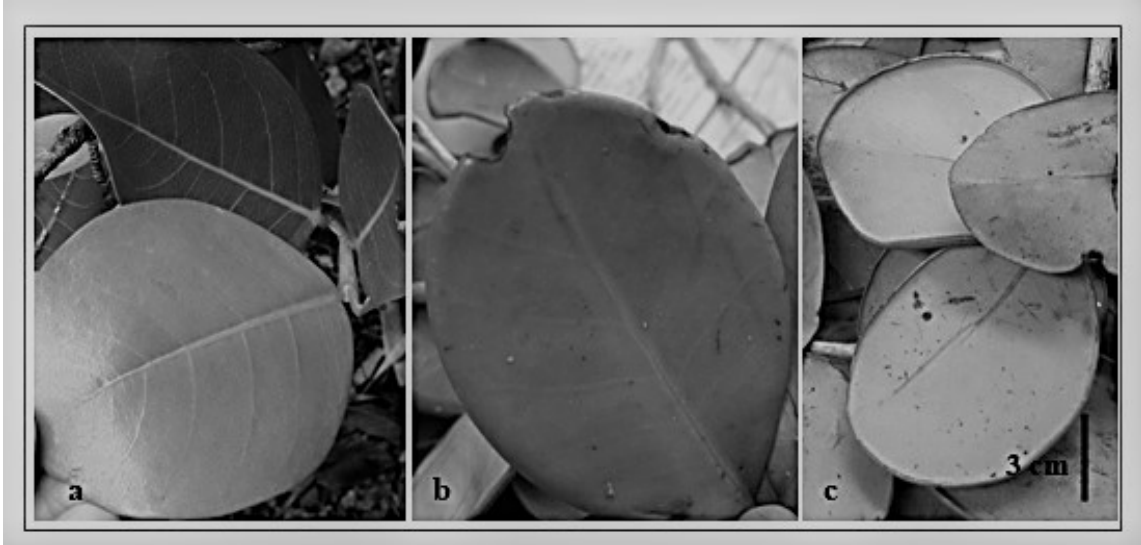

188 Fig. 2. Comparison between the branches of Chrysobalanus icaco L. 189 (Chrysobalanaceae) (a) and Eugenia astringens Cambess (Myrtaceae) (b). Abaxial part 190 of E. astringens leaf (c). Source: Photos by the author.

This misconception has been previously reported (Bochner et al., 2012; Silva and Peixoto, 2009), claiming that the trade of medicinal plants is not a safe source of sale, as it may be difficult for both the trader and the consumer to correctly identify a desirable plant. And yet there is the problem that different plants known by the same popular name are commercialized without proof of their pharmacological properties and toxicological safety (Bochner et al., 2012), besides the adulteration possibilities. Unfortunately, in Brazil, the supervision of trade of medicinal plants by regulatory agencies is still incipient.

200 Total protein concentrations ranged from 30.18 to $54.95 \mu \mathrm{g} \mu \mathrm{L}^{-1}$ in Eugenia astringens, from 28.01 to $43.88 \mu \mathrm{g} \mu \mathrm{L}^{-1}$ in Chrysobalanus icaco.

\subsection{Cytotoxicity evaluation of protein extracts}

Fibroblasts (3T3 cell line) were submitted to the cell viability assay, exposed to

206 different concentrations of protein extract and to the cell migration assay, exposed to a

207 determined concentration of this extract.

\subsubsection{Cell viability assay}

212 icaco (AL) and C. icaco (PG) on fibroblast viability, the MTT assay was performed. 
The results for the cell viability assay are shown in Fig. 3, in which it can be

214 observed and compared the reduction of fibroblasts viability among the species and 215 protein extract concentration.

216 Treatment with E. astringens (MAD) at all concentrations tested, reduced cell

217 viability, decreasing by $8.8 \%(1 \mu \mathrm{g} / \mathrm{mL}), 19.2 \%(5 \mu \mathrm{g} / \mathrm{mL}), 23 \%(10 \mu \mathrm{g} / \mathrm{mL})$ and $17 \%$

$218(20 \mu \mathrm{g} / \mathrm{mL})$ the percentage of viable cells. Exposure with C. icaco (RMA) at

219 concentrations of 1,5 and $10 \mu \mathrm{g} / \mathrm{mL}$ did not alter significantly the fibroblasts viability.

220 On the other hand, the increase in concentration resulted in a decrease in the percentage 221 of viable cells, leading to a reduction of $22.4 \%(\mathrm{P}<0.001)$ in cell viability when the 222 highest concentration $(20 \mu \mathrm{g} / \mathrm{mL})$ was used. Treatment with $C$. icaco (AL), in turn, 223 induced a decrease in cell viability (8-16\%) at all concentrations tested, when compared 224 to the control group. In addition, treatment with $C$. icaco (PG) at $1 \mu \mathrm{g} / \mathrm{mL}$ did not alter 225 the viability of fibroblasts, whereas treatment with the other concentrations induced a 226 decrease in cell viability (12-14\%).
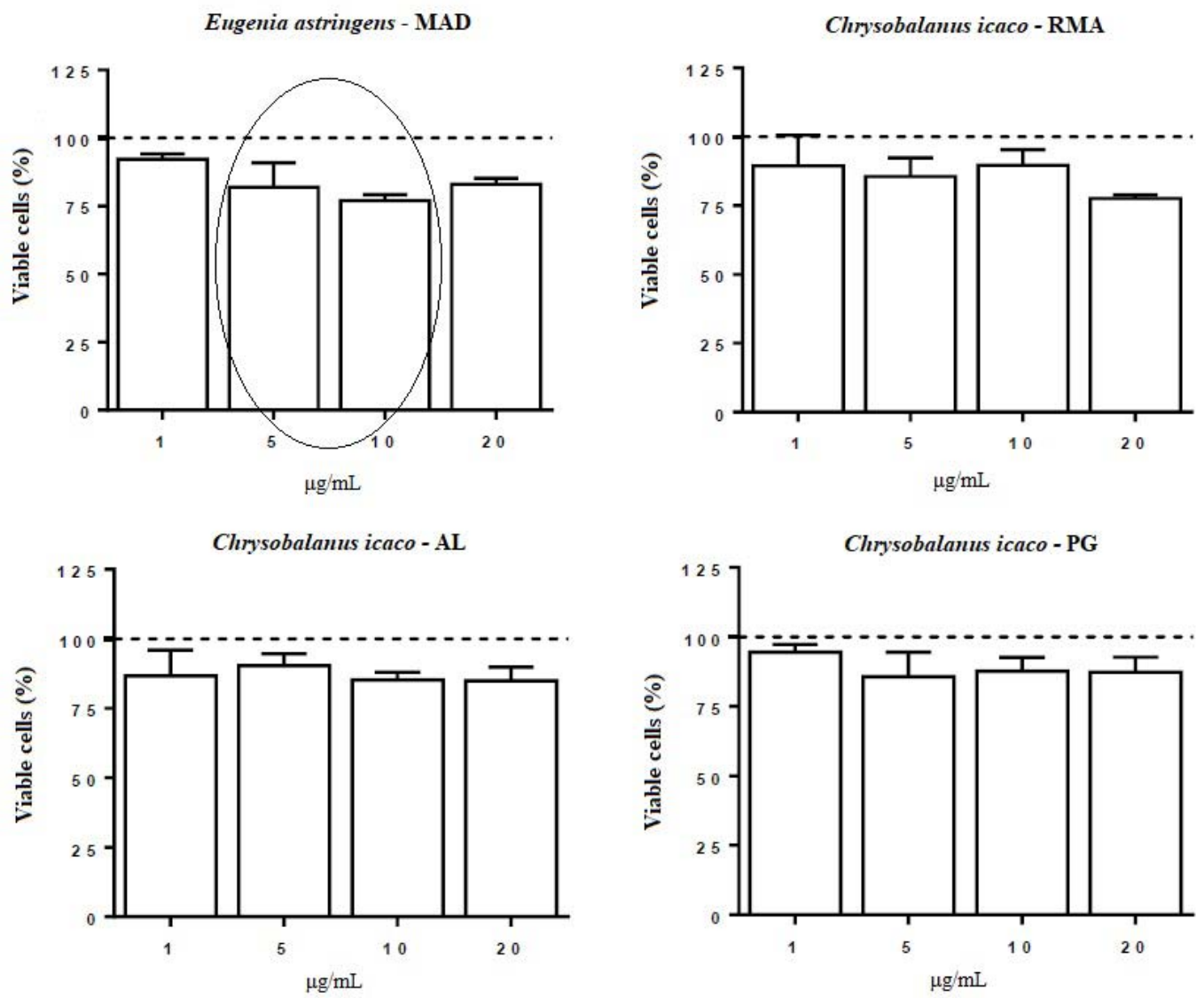

228 
Fig. 3. Effect of protein extracts of Eugenia astringens and Chrysobalanus icaco on fibroblasts viability. MAD - Mercadão de Madureira, RMA - Restinga de Massambaba, AL - Marechal Deodoro, PG - Praia Grande (PG). The dashed line represents the control group $(100 \%)$. The circle indicates high reduction on fibroblast viability for $E$. astrigens treatment. Results are mean \pm S.E.M. $\mathrm{n}=4$.

\subsubsection{Scratch wound healing assay}

To evaluate the effects of extracts of E. astringens (MAD), C. icaco (RMA), $C$. icaco (AL) and C. icaco (PG) on fibroblast migration, the cell migration assay (Scratch Wound Healing Assay) was performed.

As shown in Figure 4, treatment with $C$. icaco (RMA), $C$. icaco (AL) and $C$. icaco (PG) was not able to alter the migration rate of fibroblasts. On the other hand, it can be noted that the treatment with $E$. astringens led to a significant reduction in the migration of these cells by $26.04 \%$ ( $\mathrm{p}<0.05$ ), comparing to the control.

The migration of fibroblast is illustrated in Fig. 5, in which can be observed a lower migration of these cells when treated with E. astringens protein extract than the C. icaco treatments, slowing wound closure.

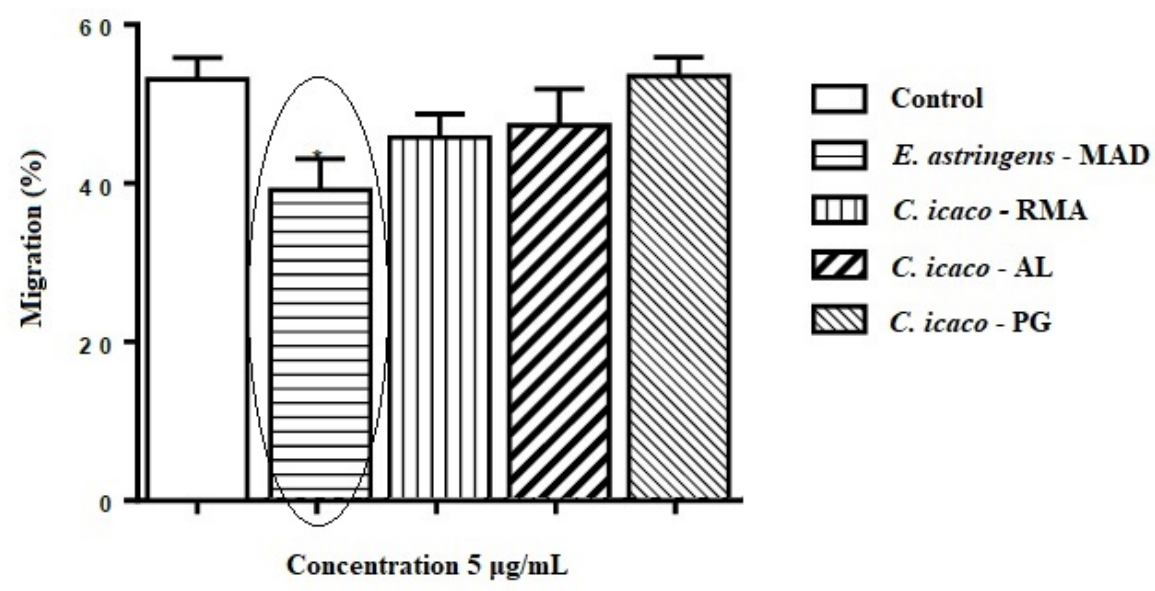

Fig. 4. Effect of the extracts of Eugenia astringens and Chrysobalanus icaco on the migration of fibroblasts at times 0 and 24 hours. MAD - Mercadão de Madureira, RMA - Restinga de Massambaba, AL - Marechal Deodoro, PG - Praia Grande (PG). Circle indicates significant reduction on fibroblast migration for E. astrigens treatment. Results are mean \pm S.E.M. One-way Anova, followed by Newman-Keuls post-test, $* p$ $<0.05 . \mathrm{n}=3$. 

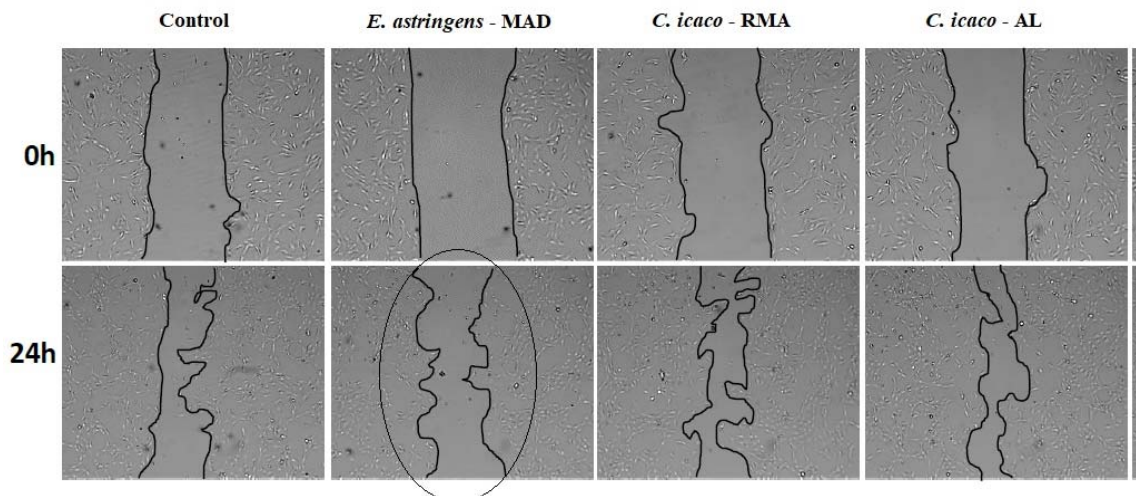

C. icaco - PG

Fig. 5. Effect of the extracts of Eugenia astringens and Chrysobalanus icaco on the migration of fibroblasts (3T3) at $0 \mathrm{~h}$ and 24 hours. MAD - Mercadão de Madureira, RMA - Restinga de Massambaba, AL - Marechal Deodoro, PG - Praia Grande. Circle indicates significant reduction on fibroblast migration for E. astrigens treatment. n=3.

\section{Discussion}

There is a misunderstanding regarding the sale of abajerú in Mercadão de Madureira, where Eugenia astringens, of the same popular name, is sold in place of Chrysobalanus icaco. This is of great concern to Public Health, because C. icaco is popularly used as medicinal plant for treating diabetes, due to its hypoglycemic potential. Meanwhile the population consumes tea from the leaves of E. astringens, coming from these markets instead of $C$. icaco. Medicinal plants are widely used due to their easy accessibility, but they usually not have their efficacy and safety well established (Bochner et al., 2012). This fact can become a risk to those who use them since they can cause more deleterious effects than bring health benefits. It is of prime importance to inspect qualified individuals, traders, distributors and producers for regularization of the sale of medicinal plants.

Silva and Peixoto (2009) raised three hypotheses regarding the introduction of Eugenia astringens, replacing Chrysobalanus icaco in popular marketing. First, it would be a strategy of the merchants to circumvent the competent oversight, by having the same popular name, but neither could it distinguish. A second hypothesis would be related to the difficulty in the recognition of the species by the collectors and sellers, as well as the consumers, due to the similar morphology. The last hypothesis would be the attribution of hypoglycemic activity to E. astringens by herbivores, since other species of Myrtaceae, such as pitanga (Eugenia uniflora L.), jambo (Eugenia jambos L.) and Eucalyptus, are used by the population for this purpose and have antioxidant, antifungal 
283 and antibacterial properties (Queiroz et al., 2015). Also, the natural environments to

284 which $C$. icaco occurs are restinga-type vegetation sites, which are usually areas of

285 environmental protection, which makes it difficult to collect specimens of this species.

286 Therefore, this could also be a hypothesis regarding the introduction of E. astringens,

287 replacing C. icaco in popular marketing. This species is not hypoglycemic like C. icaco,

288 which can lead to intoxication in those people who buy erroneously, thinking that they

289 are acquiring the correct abajerú plant.

290 Since medicinal plants may also have unknown toxicological properties, the

291 evaluation of toxicity, through in vitro tests, is required. Cytotoxicity of the extracts of

292 medicinal plants, including those that are hypoglycemic, can affect cellular processes

293 like healing that is crucial for diabetic patients. Hyperglycemia alters leukocyte

294 function, increasing the risk of bleeding and impairing inflammatory and healing

295 processes (Negri, 2005; Aquino et al., 2019). This difficulty in healing occurs due to

296 cardiovascular complications, which cause blockage or decrease of blood circulation,

297 and due to excess glucose, which can impair the functioning of the immune system.

298 That is, diseased vessels decrease blood flow, especially to the legs and feet, harming

299 the healing process and high glycemic levels incapacitate the body's defense cells (Hu et

300 al., 2002).

301 Zandi et al. (2016) verified the viability of fibroblasts (ovine line) in extracts of 302 different plants (Aloe vera, hena, camomile, licorice, myrtle, mint, cinnamon, ginger 303 and cedar) and that at the minimum concentration $(6.25 \mu \mathrm{g} / \mathrm{mL})$, the viability of dermal 304 fibroblasts by MTT assay increased significantly in cedar ( $\mathrm{p}<0.05)$. Combination of 305 Aloe vera, mint extract and licorice significantly increased the viability of dermal 306 fibroblasts $(\mathrm{p}<0.05)$. Aloe vera, which is also known for its hypoglycemic activity, has 307 the ability to stimulate proliferation of L929 fibroblasts (Manoj et al., 2009). Calloni et 308 al. (2016) tested the phenolic extract of Plinia trunciflora from the same family as $E$.

309 astringens on human lung fibroblast cells in the presence and absence of amiodarone, a 310 drug used to treat arrhythmia, but which causes toxicity in the lungs. The extract rich in 311 polyphenols was able to prevent the decrease of cellular viability (MTT test) and the 312 ATP biosynthesis.

313 There are no studies testing the viability of fibroblasts exposed to protein 314 extracts of Chrysobalanus icaco, but ethanolic extracts of these species prove to be 315 important in cellular processes. Silva et al. (2017) evaluated the antifungal activity of 316 the C. icaco ethanolic extract, noting the inhibition of growth of Candida albicans and 
C. parapsilosis, strains exposed to this extract.

Pitz et al. (2016) evaluated the in vitro activity of ethanolic extract of Plinia peruviana bark, the same family as the E. astringens, in healing processes and antioxidant activity in urinary fibroblasts (L929 cell line). The cell migration assay

321 (Scratch Wound Healing Assay) indicated that none of the tested shell concentrations $322(0.5,5,25,50$ and $100 \mu \mathrm{g} / \mathrm{ml})$ was able to increase the migration rate after 12 hours of 323 incubation. These results demonstrate a positive effect of the peel on the wound healing 324 process in the L929 fibroblast cell line, probably due to the antioxidant activity exhibited by phytochemicals in the extract. Manoj et al. (2009) verified the effect of germplasm of Aloe vera, which is also hypoglycemic in L929 fibroblasts, through the cell migration assay, confirming the increase in fibroblast migration, which is important for regeneration and skin repair in case of injury.

There are no studies testing the viability and migration of fibroblasts exposed to protein extracts of $C$. icaco and E. astringes, however ethanolic extracts are used in studies to test toxicity of Eugenia species. The in vitro antioxidant activity of the ethanolic extract of Eugenia uniflora was determined by the inhibition of spontaneous autoxidation in brain homogenate, with the $\mathrm{LD}_{50}$ of $5.93 \mathrm{~g} / \mathrm{kg}$ in mice (Auricchio et al., 2007). In the phytotoxicity test of the Eugenia catharinae extract, it was observed that ethyl acetate and hexane fractions inhibited seed germination, while the hexane fraction showed higher inhibition of lettuce seedlings. E. catharinae demonstrated a considerable toxic activity, encouraging the search for the compounds responsible for this activity (Colla and Brighente, 2011).

\section{Conclusion}

The assays to evaluate the toxicity of the protein extracts of the plants studied served to make aware of the sale and use of the Eugenia astringens plant, sold in place of Chrysobalanus icaco, since it reduced cell viability at all concentrations of the extract and decreased the fibroblast migration rate. These results showed that E. astringens can cause cytotoxic effects if consumed in larger doses.

The present work demonstrated the importance of research in the area of Public

348 Health and the dissemination and communication to society of the results of scientific 349 works since, due to the confounding of the use of medicinal plants, diabetic patients 350 may opt for natural products in therapeutic use for the treatment of diabetes, in the 
wrong way.

352

353

354

355

356

357

358

359

360

361

362

363

364

365

366

367

368

369

370

371

372

373

374

375

376

377

378

379

380

381

382

383

384

385

386

387

388

\section{Acknowledgements}

The authors are thankful to CNPq, to CAPES and to Dra. Viviane Kruel from the Research Institute of Botanical Garden of Rio de Janeiro for the identification of the specimens collected. The cytotoxicity assays were performed at the Laboratory of Cell Biology of the Federal University of Alagoas under the supervision of Dr. Emiliano Barreto. This study was carried out with financial support from the Coordination and Improvement of Higher Level or Education Personnel - CAPES (PhD's grant).

\section{References}

Aquino, J.A., Baldoni, A.O, Oliveira, C.L., Cardoso, C.S., Figueiredo, R.C., Sanches, C. 2019. Pharmacotherapeutic empowerment and its effectiveness in glycemic control in patients with Diabetes Mellitus. Diabetes Metab. Syndr.: Clinical Research \& Reviews 13 (1), 137-142.

Auricchio, M.T., Bugno, A., Barros, S.B.M., Bacchi, E.M. 2007. Atividades antimicrobiana e antioxidante e toxicidade de Eugenia uniflora. Lat. Am. J. Pharm., 26 (1), 76-81.

Bochner, R., Fiszon, J.T., Assis, M.A., Avelar, K.E.S. 2012. Problemas associados ao uso de plantas medicinais comercializadas no Mercadão de Madureira, município do Rio de Janeiro, Brasil. Revista Brasileira Plantas Medicinais 14 (3), 537-547.

Calloni, C., Silva-Santos, L.F., Martínes, L.S., Salvador, M. 2016. Data in brief data on cell viability of human lung fibroblasts treated with polyphenols-rich extract from Plinia. Data in Brief 6, 728-731.

Colla, G, Brighente, I.M.C. 2011. Potencial tóxico dos extratos de Eugenia catharinae. In: $51^{\circ}$ Congresso Brasileiro de Química, 7 (136).

Hu, F.B., Stamper, M.J., Haffner, S.M., Solomon, C.G., Willett, W.C., Manson, J.E. 2002. Elevated risk of cardiovascular disease of type 2 diabetes. Diabetes Care 25, 1129-1134.

Liang, C., Park, A.Y., Guan, J. 2007. In vitro scratch assay: a convenient and inexpensive method for analysis of cell migration in vitro. Nature Protocols 2 (2), 329333.

Manoj, K., Mishra, D., Maity, T.K., Gupta, S.D. 2009. Screening wound-healing potential of different Aloe vera $\mathrm{L}$. germplasms at the cellular level. Medicinal and Aromatic Plant Science and Biotechnology 3 (1), 2-4.

Moosa, A., Farzand, A., Sahi, T.S., Khan, S.A. 2017. Transgenic expression of 
389 antifungal pathogenesis-related proteins against phytopathogenic fungi - 15 years of

390 success. Israel Journal of Plant Science, doi: 10.1080/07929978.2017.1288407.

391 Mosmann, T. 1983. Rapid colorimetric assay for cellular growth and survival:

392 Application to proliferation and cytotoxicity assays. Journal of Immunology Methods

$393 \mathbf{6 5}(1), 55-63$.

394 Negri, G. 2005. Diabetes melito: plantas e princípios ativos naturais hipoglicemiantes.

395 Revista Brasileira Ciências Farmacêuticas 41 (2), 121-142.

396 Pitz, H.S., Pereira, A., Blasius, M.B., Voytena, A.P.L., Affonso, R.C.L., Fanan, S.,

397 Trevisan, A.C.D., Ribeiro-do-Valle, R.M., Maraschin, M. 2016. In vitro evaluation of 398 the antioxidant activity and wound healing properties of jaboticaba (Plinia peruviana) 399 fruit peel hydroalcoholic extract. Oxidative Medicine and Cellular Longevity 3, 1-6.

400 Queiroz, J.M.G., Suzuki, MC.M., Motta, A.P.R., Nogueira, J.M.R., Carvalho, E.M. 401 2015. Aspectos populares e científicos do uso de espécies de Eugenia como fitoterápico. 402 Revista Fitos 9 (2), 73-159.

403 Santos, K.M., Gomes, I.N.F., Silva-Oliveira, R.J., Pinto, F.E., Oliveira, B.G., Chagas, 404 R.C.R., Romão, W., Reis, R.M.V., Ribeiro, R.I.M.A. 2018. Bauhinia variegata candida 405 fraction induces tumor cell death by activation of caspase-3, RIP, and TNF-R1 and 406 inhibits cell migration and invasion in vitro. BioMed Research International 2018, 1-10.

407 Sharma, S.S., Dietz, K. 2006. The significance of amino acids and amino acid-derived 408 molecules in plant responses and adaptation to heavy metal stress. Journal of 409 Experimental Botany 57 (4), 711-726.

410 Sharma, S.S., Dietz, K. 2008. The relationship between metal toxicity and cellular redox 411 imbalance. Cell Press 14 (1), 43-50.

412 Silva, I.M., Peixoto, A.L. 2009. O abajurú (Chrysobalanus icaco L. e Eugenia 413 rotundifolia Casar.) comercializado na cidade do Rio de Janeiro, Brasil. Brazilian 414 Journal of Pharmacognosy 19 (1b), 325-332.

415 Silva, J., Peres, A.R., Paixão, T.P., Silv,a A.S, Baetas, A.C., Barbosa, W.L., Monteiro, 416 M.C., Andrade, M.A. 2017. Antifungal activity of hydroalcoholic extract of 417 Chrysobalanus icaco against oral clinical isolates of Candida species. Pharmacognosy 418 Research 9 (1), 96-100.

419 Stockert, J.C., Blázquez-Castro, A., Cañete, M., Horobin, R.W., Villanueva, A. 2012. 420 MTT assay for cell viability: Intracellular localization of the formazan product is in 421 lipid droplets. Acta Histochemica 114 (8), 785-796.

422 Stockert, J.C., Horobin, R.W., Colombo, L.L., Blázquez-Castro, A. 2018. Tetrazolium 423 salts and formazan products in cell biology: Viability assessment, fluorescence imaging, 424 and labeling perspectives. Acta Histochemica 120 (3), 159-167.

425 Venancio, V.P., Almeida, M.R., Antunes, L.M.G. 2018. Cocoplum (Chrysobalanus icaco 426 L.) decreases doxorubicin-induced DNA damage and downregulates Gadd45a, Il-1 $\beta$, 427 and Tnf- $\alpha$ in vivo. Food Research International 105, 996-1002. 
428 White, P.A.S., Araújo, J.M., Cercato, L.M., Souza, L.A., Barbosa, A.P., Quintans-Junior, 429 L.J., Machado, U.F., Camargo, E.A., Brito, L.C., Santos, M.R. 2016. Chrysobalanus 430 icaco L. leaves normalizes insulin sensitivity and blood glucose and inhibits weight gain 431 in high-fat diet-induced obese mice. Journal of Medicinal Food 19 (2), 155-160.

432 Zandi, M., Masoumian, M., Shariatinia, A., Sanjabi, M.R. 2016. Optimal concentrations 433 and synergistic effects of some herbal extracts on viability of dermal fibroblasts. Gene 434 Cell Tissue 3 (4), 1-7.

435

436 


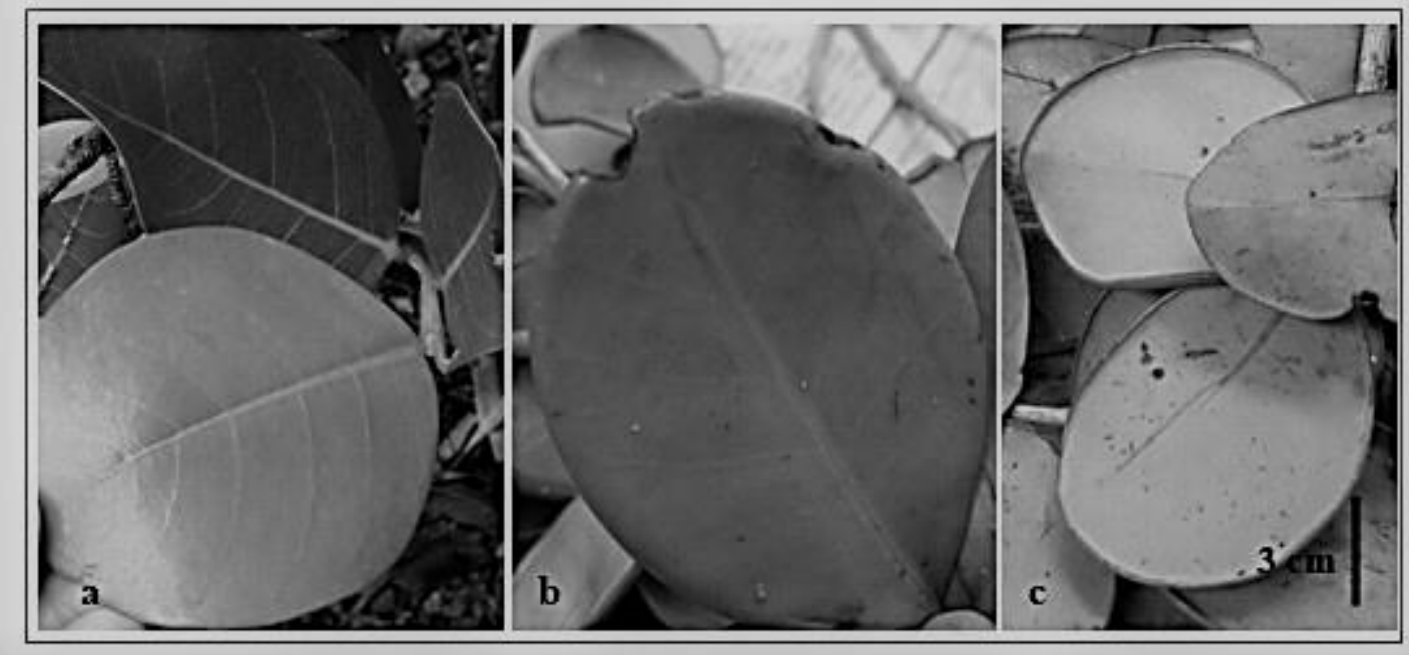


Eugenia astringens - MAD

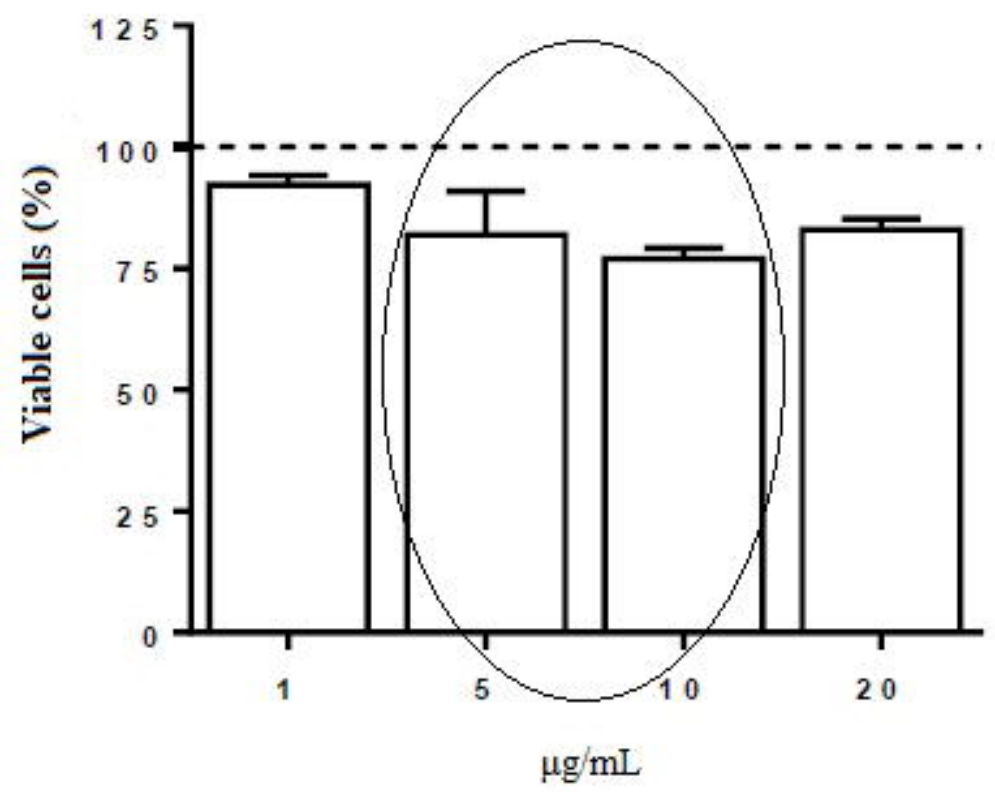

Chrysobalanus icaco - AL

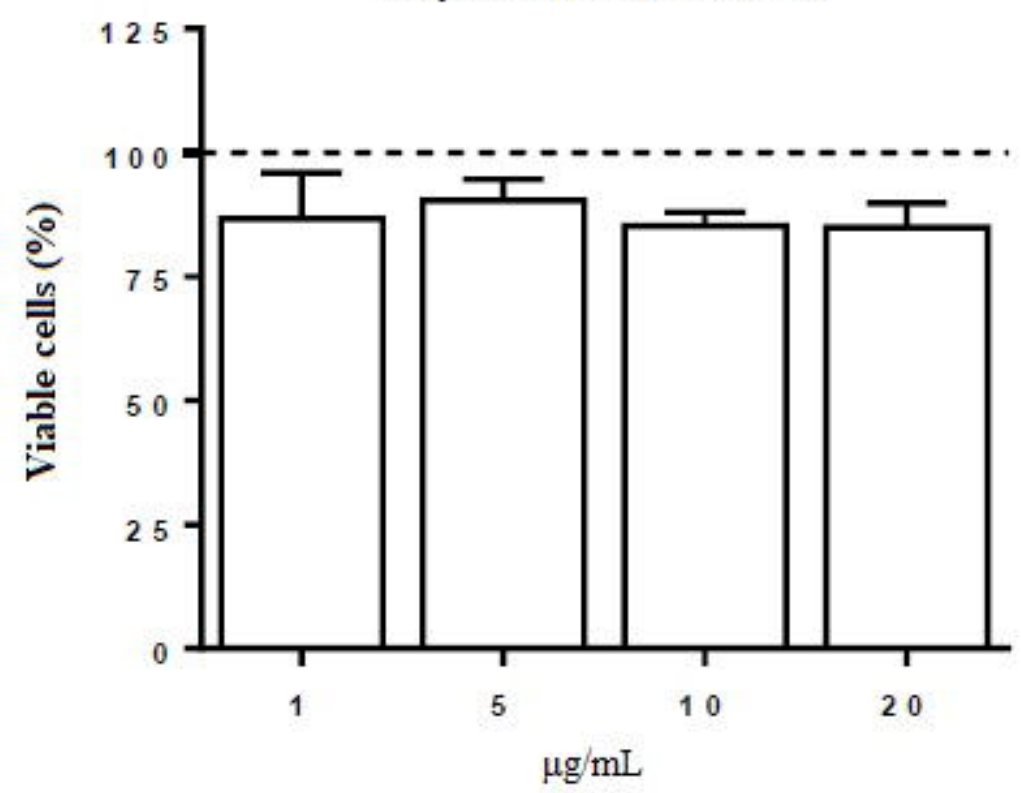

Chrysobalanus icaco - RMA

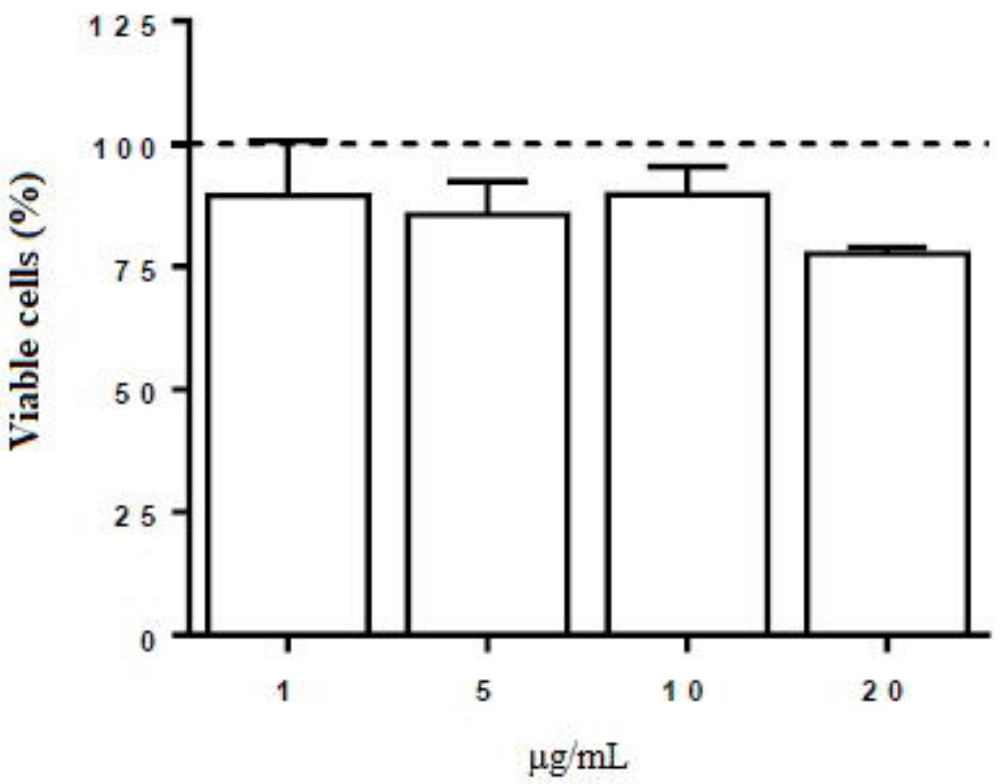

Chrysobalanus icaco - PG

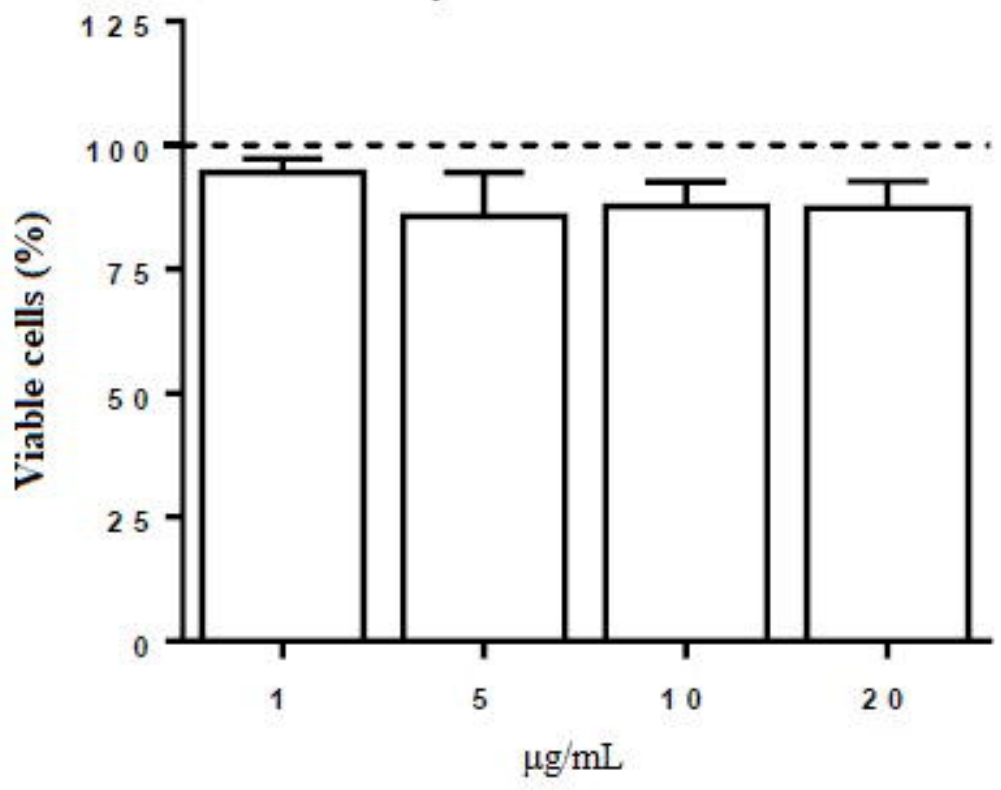




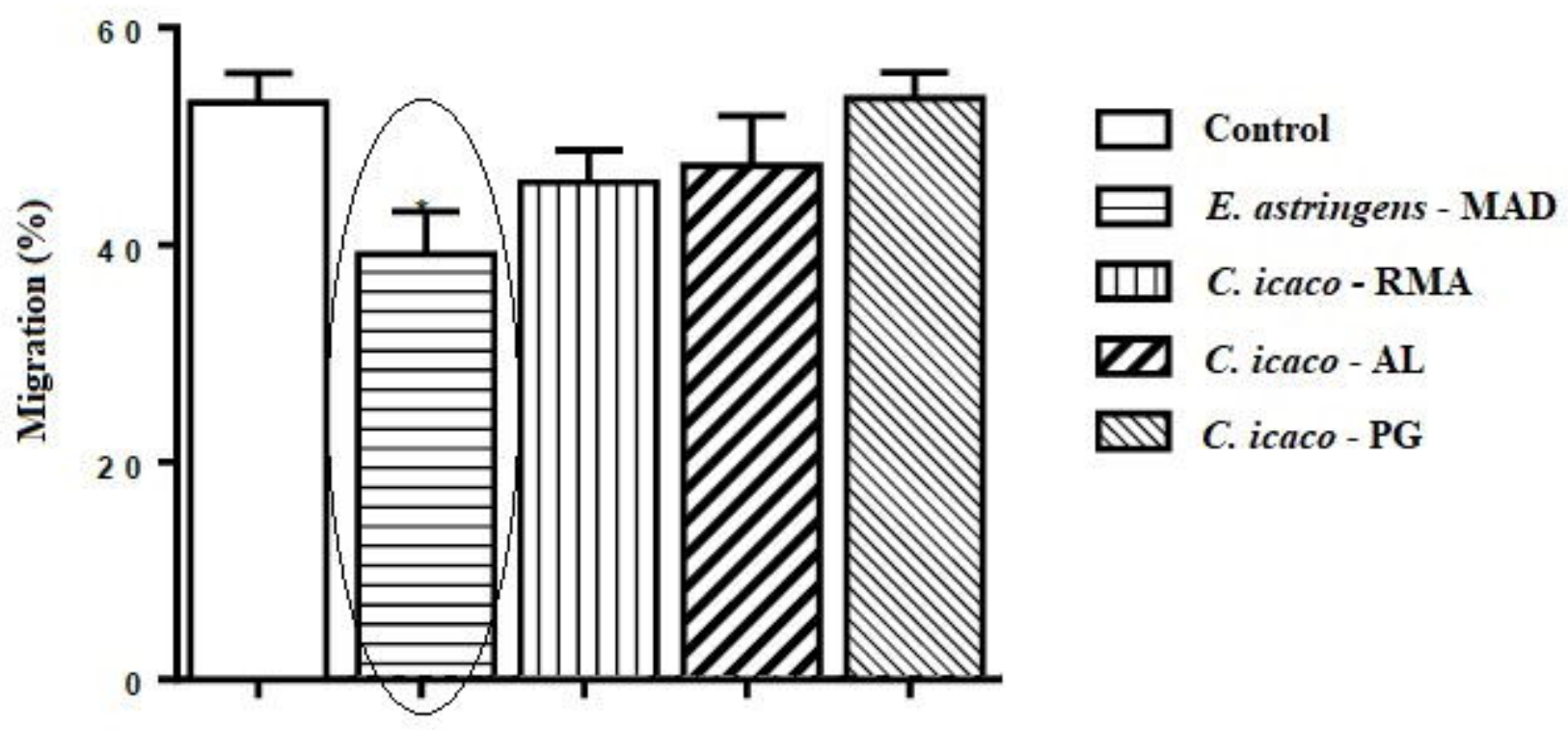

Concentration $5 \mu \mathrm{g} / \mathrm{mL}$ 


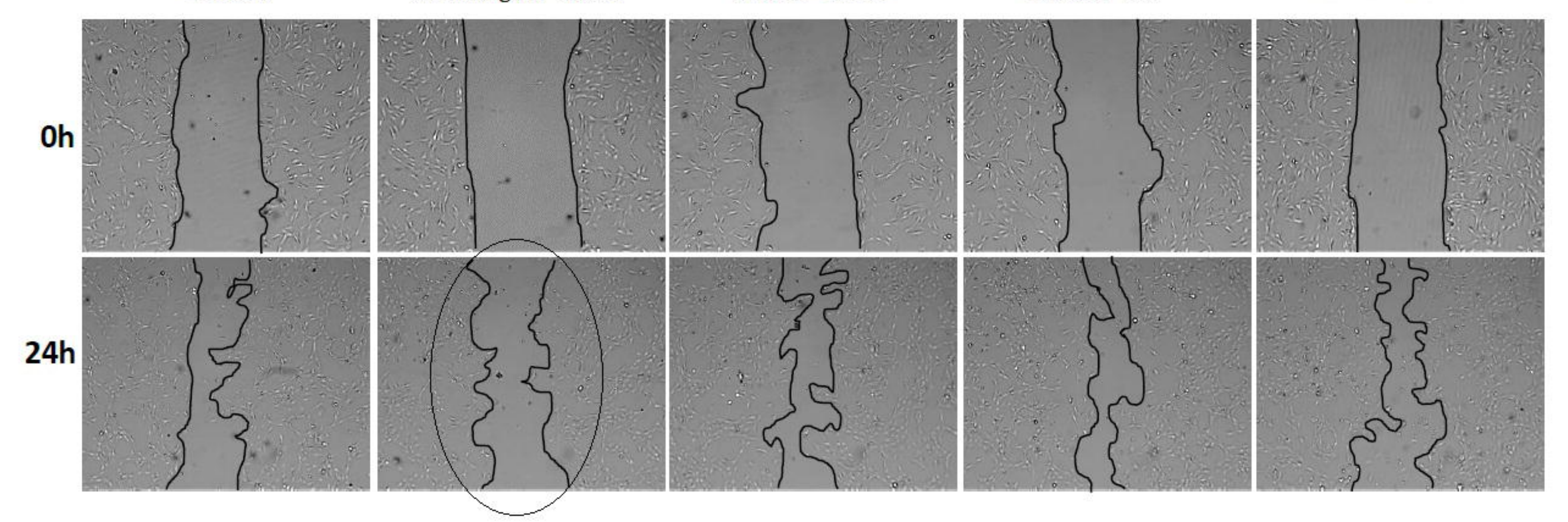

